Acta horticulturae et regiotecturae 1

Nitra, Slovaca Universitas Agriculturae Nitriae, 2014, p. 13-15

\title{
EVALUATION OF POPULATION REGULATION OF INVASIVE SPECIES FALLOPIA $\times$ BOHEMICA BY REPEATED MOWING
}

\author{
Lýdia KONČEKOVÁ*, Helena ŠEBOVÁ, Eduard PINTÉR \\ Slovak University of Agriculture in Nitra, Slovak Republic
}

\begin{abstract}
Population regulation of invasive species Fallopia $\times$ bohemica by repeated mowing was evaluated in experimental research plots in Babindol and Klasov. The mowings were carried out repeatedly (three mowings) during the growing season 2010. The statistical evaluation confirmed that the mechanical regulation of populations of Fallopia $\times$ bohemica significantly influenced the dynamics of shoot height as well as the diameter at the base of a stem. Significantly less marked decline of the population density had occured after the $2^{\text {nd }}$ mowing. For the best controll in the future, we suggest the application of mechanical regulation in shorter intervals depending on a growth rate.
\end{abstract}

Keywords: alien plants, Fallopia $\times$ bohemica, mechanical regulation, mowing

Invasive plant species are included among the most important factors that currently pose threats to biodiversity. Therefore, it is necessary to ensure a radical management treatments resulting from the knowledge of these species (Child and Wade, 2000; Wittenberg and Cock, 2001; Myers and Bazely, 2003; EEA, 2010). There is a number of methodological manuals that would eradicate the genus Fallopia in successful way (e.g. Child and Wade, 2000; Bímová, Mandák and Pyšek, 2001; Cvachová a Gojdičová, 2003; Šrubař, 2007; Barták et al., 2010). Mechanical techniques (mowing, cutting, uprooting etc.) are preferred in the cases when the population of invasive species occupies a small area, or a few individuals or seedling occur, or if invasive plants growth in protected areas (Zárubová-Prausová, 2001). The disadvantage of those methods is that intensive manual work always prevails and regulation must be repeated for several years to remove all individuals (Wittenberg and Cock, 2001). The appropriately carried out methods to remove invasive plant species result in a restoration of degraded communities and their increased resistance to spreads of alien species (DiTomaso, 2000). The objective of the study was to evaluate the population regulation of invasive species Fallopia $\times$ bohemica (Chrtek and Chrtková) by repeated mowing in selected villages (the Nitra district area, SW Slovakia).

\section{Material and methods}

The cadastral zones of Klasov and Babindol belong to the region of the West Pannonian Basin and the Danubian Lowland region (approx. 15-17 km east from Nitra to Vráble). Both are located on a flat ridge of the central part of Žitava hills in the valley of the Babindolský water stream, and to southeast of the municipalities flows the Hostovský water stream (SW Slovakia). Both regulated streams are right tributaries of the river Žitava (Kropilák et al., 1977). The altitude of the central part of Klasov and Babindol is $177 \mathrm{~m} \mathrm{ASL}$ and $205 \mathrm{~m} \mathrm{ASL}$, respectively. The climate of the region is warm, dry, with mild winters (average annual temperature of 9.7 to $10{ }^{\circ} \mathrm{C}$ ). The main soil unit is haplic luvisol, locally eroded; agricultural soils are very fertile. In terms of agricultural use, the landscape is a type with a high rate of agricultural production and growing area of barleywheat-sugar, beet-maize-viticulture (Mazúr a Lukniš, 1980; Michalko et al., 1986).

For the experiment, 3 permanent research plots of Fallopia $\times$ bohemica in Babindol (PRP1, in an anthropogenic habitat, near the village cemetery) and Klasov (PRP2 and PRP3, near the regulated stream) were established. The observations were made during the growing season of 2010 (the area of one plot was $1 \mathrm{~m}^{2}$ ). In the prescribed terms (May $30^{\text {th }}, 2010$, August $22^{\text {nd }}, 2010$, and November $5^{\text {th }}, 2010$ ), the selected quantitative characteristics (population density, height of the individual, $s$ and diameter of stems) were evaluated and the stands were mowed. One plant shoot (ramet) of polycormon was considered as an individual. From remnant area, all above-ground biomass of polycormon was removed to avoid the support of plant individuals through rhizomes. Dry weight of above-ground biomass was weighed in laboratory conditions (drying at $105^{\circ} \mathrm{C}$ ). The obtained data was tested by ANOVA (Statgraphics, Tukey's test) for detecting the significant differences.

\section{Results and discussion}

\section{Evaluation of population density}

By evaluation of population density we found that after the first mechanical regulation, the number of individuals increased in each of the three PRPs. The increase in the population density between the first and the second mowing was within the interval $8.3 \%$ to $12.5 \%$ according to a PRP and it could be influenced by the strong support from rhizomes as well as status of climate conditions that contribute to the resumption and regeneration of populations. The opposite situation was found between 


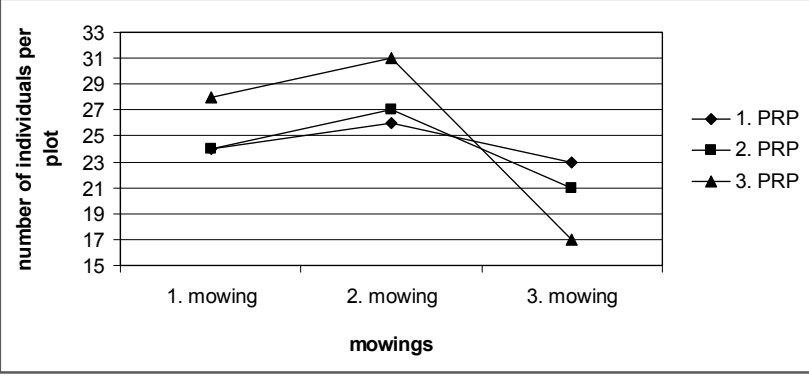

Figure 1 Evaluation of population density in the PRPs with mechanical regulation during the vegetation period 2010

the second and the third mowing. The lowest number of individuals was recorded at the third mowing in all of the PRPs. The decrease in the population density between the second and the third mowing was within the interval $11.53 \%$ to $45.16 \%$ according to a PRP.

Lisyová (2000) found out the decrease in population density in August (42.85\%) on unregulated plots in SW Slovakia. Similarly, Halmová and Fehér (2009) recorded the highest density in May and September 2007 and in May and November 2008 and the lowest one in August 2007. The authors explained that the variation of density is caused by intra-competition of ramets. In our permanent research plots we recorded the highest number of individuals in August and the lowest one in November. Fibichová (2010) found out the decrease in the population density of about $30.30 \%$ with application of one mowing in summer on regulated research plots. Similar results were recorded between the second and the third mowing, when the population density decreased in average of $23.60 \%$.

\section{Population size structure and diameter growth}

We found the maximum mean height and thickness of stems in May. After each of the mowings, the new formed shoots were lower and thinner. In the $1^{\text {st }}$ permanent research plot, canopy had the mean height $259 \mathrm{~cm}$ at the first mowing

Table 1 Statistical evaluation of the impact of mowing on height of individuals of Fallopia $\times$ bohemica in PRPs

\begin{tabular}{|l||c|c|c|}
\hline $\begin{array}{l}\text { Permanent } \\
\text { research plot }\end{array}$ & $\begin{array}{c}\text { Height of } \\
\text { shoots }\end{array}$ & Mowing & $\begin{array}{c}\text { Homogenous } \\
\text { group }\end{array}$ \\
\hline \hline \multirow{3}{*}{ 1. } & \multirow{3}{*}{++} & 3 & $88.15 \mathrm{a}$ \\
\cline { 3 - 4 } & & 2 & $144.11 \mathrm{~b}$ \\
\cline { 3 - 4 } & \multirow{3}{*}{ 2. } & 1 & $252.33 \mathrm{c}$ \\
\hline & \multirow{3}{*}{ 3. } & 3 & $84.22 \mathrm{a}$ \\
\hline & & 1 & $140.26 \mathrm{~b}$ \\
\hline & \multirow{3}{*}{++} & 3 & $268.15 \mathrm{c}$ \\
\cline { 3 - 4 } & & 2 & $119.91 \mathrm{~b}$ \\
\cline { 3 - 4 } & & 1 & $183.97 \mathrm{c}$ \\
\hline
\end{tabular}

Values followed by the different letters column-wise were significantly different in the Tukey test $(p<0.05)$; ++ statistically highly significant difference between the mowings
Table 2 Statistical evaluation of the impact of mowing on thickness of individuals of Fallopia $\times$ bohemica on PRPs

\begin{tabular}{|c|c|c|c|}
\hline $\begin{array}{l}\text { Permanent } \\
\text { research plot }\end{array}$ & $\begin{array}{l}\text { Diameter at the } \\
\text { base of stem }\end{array}$ & Mowing & $\begin{array}{c}\text { Homogenous } \\
\text { group }\end{array}$ \\
\hline \multirow{3}{*}{1.} & \multirow{3}{*}{++} & 3 & $0.53 \mathrm{a}$ \\
\hline & & 2 & $1.19 \mathrm{~b}$ \\
\hline & & 1 & $1.88 \mathrm{c}$ \\
\hline \multirow{3}{*}{2.} & \multirow{3}{*}{++} & 3 & $0.61 \mathrm{a}$ \\
\hline & & 2 & $1.16 \mathrm{~b}$ \\
\hline & & 1 & $2.08 \mathrm{C}$ \\
\hline \multirow{3}{*}{3.} & \multirow{3}{*}{++} & 3 & $0.63 a$ \\
\hline & & 2 & $0.85 b$ \\
\hline & & 1 & $1.51 \mathrm{c}$ \\
\hline
\end{tabular}

Values followed by the different letters column-wise were significantly different in the Tukey test $(p<0.05)$; ++ statistically highly significant difference between the mowings

and only $87.7 \mathrm{~cm}$ at the third mowing (difference: $33.86 \%$ ). A similar phenomenon was observed regarding the height of the plants in the other research plots where the decline was $30.38 \%$ and $40.97 \%$ individuals per plot between the $1^{\text {st }}$ and the $3^{\text {rd }}$ mowing. For comparison, in the $1^{\text {st }}$ permanent research plot, shoots had the mean diameter $1.81 \mathrm{~cm}$ at the first mowing and only $0.47 \mathrm{~cm}$ at the third mowing ( $26.03 \%$ relative decrease). A similar situation was observed regarding the thickness of the plants in the other research plots where the difference was $27.40 \%$ and $38.85 \%$ per plot between the 1 st and the 3rd mowing. Analysis of variance confirmed statistically significant differences in terms of impact of mowing on height and thickness of individuals in each research plot (see Table 1 and Table 2).

Comparison of size growth of individuals and population density revealed that in August, when the number of individuals reached its maximum, the mean height of individuals was lower by $102.5 \mathrm{~cm}$ in average and the mean diameter of stem by $0.79 \mathrm{~cm}$ in average, compared to the previous measurement according to a PRP.

\section{Evaluation of dry mass of above-ground biomass}

At the end of May, the dry mass of above-ground organs had maximum rates in all the PRPs. In this period of growing season, the shoots reached maximum height, stem diameter, number of internodes and leaves, and lateral branches and populations created monodominant and dense canopies. Within the $1^{\text {st }}$ and the $3^{\text {rd }}$ mowing, the difference of mean dry mass by $793.48 \mathrm{~g}$ (42.61\%) (Fig. 2) was observed.

The total dry weight of biomass for every research plot was $2.49 \mathrm{~kg} \cdot \mathrm{m}^{-2}, 3.30 \mathrm{~kg} \cdot \mathrm{m}^{-2}$ and $2.09 \mathrm{~kg} \cdot \mathrm{m}^{-2}$ in the $1^{\text {st }}, 2^{\text {nd }}$ and $3^{\text {rd }}$ PRP, respectively during the growing season 2010. The results are comparable with Fibichová (2010) from populations of Fallopia $\times$ bohemica with application of one mowing where the total amount of dry mass was $2.78 \mathrm{~kg} \cdot \mathrm{m}^{-2}$, and Halmová and Fehér (2009) reported the total dry mass of $3.07 \mathrm{~kg} \cdot \mathrm{m}^{-2}$ (2007) and $2.63 \mathrm{~kg} \cdot \mathrm{m}^{-2}$ (2008) from populations without control. 


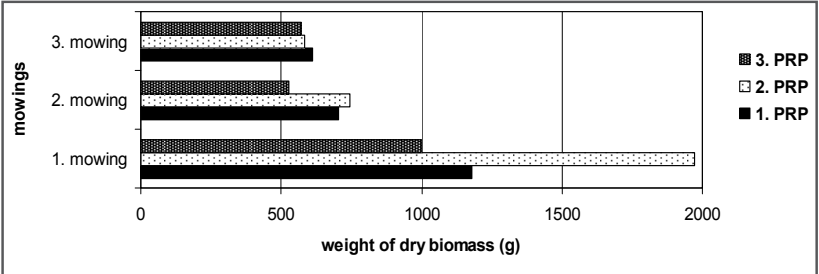

Figure 2 Weight of dry biomass during the vegetation period 2010

\section{Conclussion}

Statistical evaluation confirmed that the mechanical regulation of populations of Fallopia $\times$ bohemica (three mowings during a growing season) significantly reduced the height as well as the thickness of shoots. Significantly lower decline of the population density occured after the $2^{\text {nd }}$ mowing. In accordance with our methodology we proposed the application of mowings in spring and in autumn (specifically applied four mowings from May to June and three mowings from August to the end of a vegetation period).

\section{Summary}

Except for preventive treatments for control of invasive species, radical management treatments based on research results are necessary, too. The aim of the paper was to evaluate the population regulation of invasive species Fallopia $\times$ bohemica by repeated mowing in the selected villages Babindol and Klasov (the Nitra district area, SW Slovakia) in growing season of 2010. Decline in the height and thickness of shoots was the result of the repeated mowing application. Comparing the size of individuals and the population density, we found that in August, when the number of individuals had maximum, the mean height of individuals was lower by $102.5 \mathrm{~cm}$ in average, and the mean thickness of stems by $0.79 \mathrm{~cm}$ in average in comparison with the previous measurement according to a PRP. The evaluation of dry above-ground biomass showed high amount of biomass at the $1^{\text {st }}$ mowing in every research plot. In this period of growing season, the shoots reached maximum height and stem diameter, and populations created monodominant and dense canopies. The difference in the mean dry biomass between the $1^{\text {st }}$ and the $2^{\text {nd }}$ mowing was $724.25 \mathrm{~g}$, but between the $2^{\text {nd }}$ and the $3^{\text {rd }}$ mowing it was only $69.23 \mathrm{~g}$, which could be caused by climatic conditions. Although the application of three mowings during the growing season affected the significance of the height and the diameter growth of shoots, the total weight of the biomass at the end of the growing season is comparable to the biomass achieved in plantations without mechanical control or biomass from the stands with the application of one mowing.

\section{References}

BARTÁK, R. et al. 2010. Metodika likvidace inváznich druhů křídlatek (REYNOUTRIA SPP.). Český Těšín : Moravskoslezký kraj a ČSOP Salamandr, 2010. $31 \mathrm{~s}$.
BÍMOVÁ, K. - MANDÁK, B. - PYŠEK, P. 2001. Experimental control of Reynoutria congeners: a comaprative study of a hybrid and its parents. In: Brundu, G. et al. (eds) Plant Invasion: Species Ecology and Ecosystem Management. Backuys Publishing, Leiden pp. 283-290.

CBD. 2013. What's the Problem? [online]. 2013. [quot. 04-15-2013] Available online: http://www.cbd.int/invasive/WhatarelAS.shtml

CHILD, L. - WADE, M. 2000. The Japanese knotweed manual: the management and control of an invasive alien weed. Packard Publishing Ltd, Chichester, UK, 2000, pp xi + 123 pp

CVACHOVÁ, A. - GOJDIČOVÁ, E. 2003. Usmernenie na odstraňovanie inváznych druhov rastlín. Banská Bystrica : ŠOP SR, 2008. 68 s. ISBN 80-89035-25-6.

Di TOMASO, J. M. 2000. Invasive weeds in rangelands: Species, impacts, and management. Weed Science, 2000 , no. 48, p. 255-265

EEA 2010. EU 2010. biodiversity baseline.EEA : Copenhagen 2010, 211 pp. ISSN 1725-2237

FIBICHOVÁ, J. 2010. Hodnotenie možnosti využitia energetických bylín na výrobu energie (Fallopia spp.). Záverečná práca : Nitra : SPU. 2010, s. 54

HALMOVÁ, D. - FEHÉR, A. 2009. Možnosti využívania fytomasy inváznych druhov bylín na výrobu biopalív a tepelnej energie. In: Acta regionalia et environmentalica, 2009, č. 2, s. 49-53.

LISYOVÁ, J. 2000. Štruktúra a dynamika populácie invadujúceho druhu Fallopia japonica (Houtt.). In: Eliáš, P. (ed.): Populačná biológia rastlín VI. SEKOS, Bratislava-Nitra, 2000, s. 173-181

KROPILÁK, M. a i. 1977. Vlastivedný slovník obcí na Slovensku. I. Bratislava : Veda, $528 \mathrm{~s}$

MAZÚR, E. - LUKNIŠ, M. 1980. Geomorfologické jednotky. In: Mazúr, E. et al., 1980. Atlas SSR. Bratislava : Vydavatel'stvo SAV, s. 55.

MICHALKO, J. a i. 1986. Geobotanická mapa ČSSR, textová čast'. Bratislava : Vydavatel'stvo SAV, 1986. $160 \mathrm{s.}$

MYERS, J. H. - BAZELY, D. R. 2003. Ecology and control of introduced plants. Cambridge : Cambridge University Press, 2003. 313 p.

ŠRUBAŘ, M. 2007. Návod na likvidaci tři druhů křídlatek. Kunčice p. O.: ZO ČSOP. 2007.

WITTENBERG, R. - COCK, M. J. W. (eds.). 2001. Invasive alien species: A toolkit of best prevention and management practise. CAB International, Wallingford, Oxon, xii - 228

ZÁRUBOVÁ-PRAUSOVÁ, R. 2000. Invaze zavlečených rostlinných druhů v České republice. Část 1. Ochrana prírody, roč. 55, 2000, č. 10, p. 295-298.

\section{Contact address:}

Ing. Lýdia Končeková, PhD., Slovak University of Agriculture in Nitra, Faculty of European Studies and Regional Development, Department of Ecology, Mariánska 10, 949 01 Nitra, Slovak Republic, phone: +421 3764156 18, e-mail: lydia.koncekova@uniag.sk 